\title{
鴒 New Disease Reports \\ A new disease, bacterial black rot of Korean radish, caused by Acidovorax konjaci
}

\author{
I.-S. Myung ${ }^{1 *}$, Y.-K. Lee ${ }^{1}$, I.H. Jeong ${ }^{1}$, S.Y. Moon ${ }^{1}$, S.W. Lee ${ }^{2}$ and H.S. Shim ${ }^{1}$ \\ ${ }^{1}$ Crop Protection, National Academy of Agricultural Science (NAAS), Rural Development Administration (RDA), Suwon \\ 441-707, Korea ; ${ }^{2}$ Agricultural Microbiology, NAAS, RDA, Suwon 441-707, Korea
}

*E-mail: ismyung@ @rda.go.kr

Received: 23 Mar 2010. Published: 26 Oct 2010. Keywords: Raphanus sativus, 16S rRNA gene

Korean radish (Raphanus sativus) is an important vegetable crop in Korea, and is cultivated on 4,095 ha, producing 234,681 metric tonnes in Jeju island (http://www.agri.jeju.kr). In November, 2008, a new bacterial disease was observed in a commercial radish field (Fig. 1). Disease incidence was found to be $38 \%$ in 100 uprooted radish roots in the field. Brownish-black symptoms were observed on both exterior and interior of roots of overwintering Korean radish, significantly reducing the value of the agricultural product. Six bacterial isolates were recovered on trypticase soy agar (TSA) from diseased root tissues and from leaf spot lesions surface-sterilized in $70 \%$ ethanol for one minute. The isolates were Gram-negative aerobic rods each with a single flagellum, which produced white colonies on TSA.

Pathogenicity was confirmed by inoculation of two slices of roots of Korean radish per isolate with a bacterial suspension $\left(1 \times 10^{8} \mathrm{cfu} / \mathrm{ml}\right)$ in sterile distilled water in a moist chamber at $28^{\circ} \mathrm{C}$. All isolates and the reference strain of Acidovorax konjaci ${ }^{\mathrm{T}}\left(\mathrm{KACC} 10652^{\mathrm{T}}\right.$ ) induced symptoms observed on naturally infected roots. Inoculated parts of the root slices turned brown four days after inoculation (Fig. 2A). The discoloured symptoms spread onto the root surface and turned the inner and outer parts of the root slices black within 25 days after inoculation (Fig. 2B). Bacteria re-isolated 20 days after inoculation from the diseased parts surface-sterilized in $70 \%$ ethanol satisfied Koch's Postulates. Identity of the re-isolated bacteria was confirmed by sequencing $16 \mathrm{~S}$ rDNA using universal primers. No symptoms were observed on root slices inoculated with sterilised distilled water. Using the Biolog Microbial Identification System, Version 4.2 (Biolog Inc., Hayward, USA), all isolates gave highly similar profiles to that of the reference strain of $A$. konjaci $^{\mathrm{T}}$, and were so identified with a Biolog similarity index of a range of 0.51 to 0.68 . A PCR
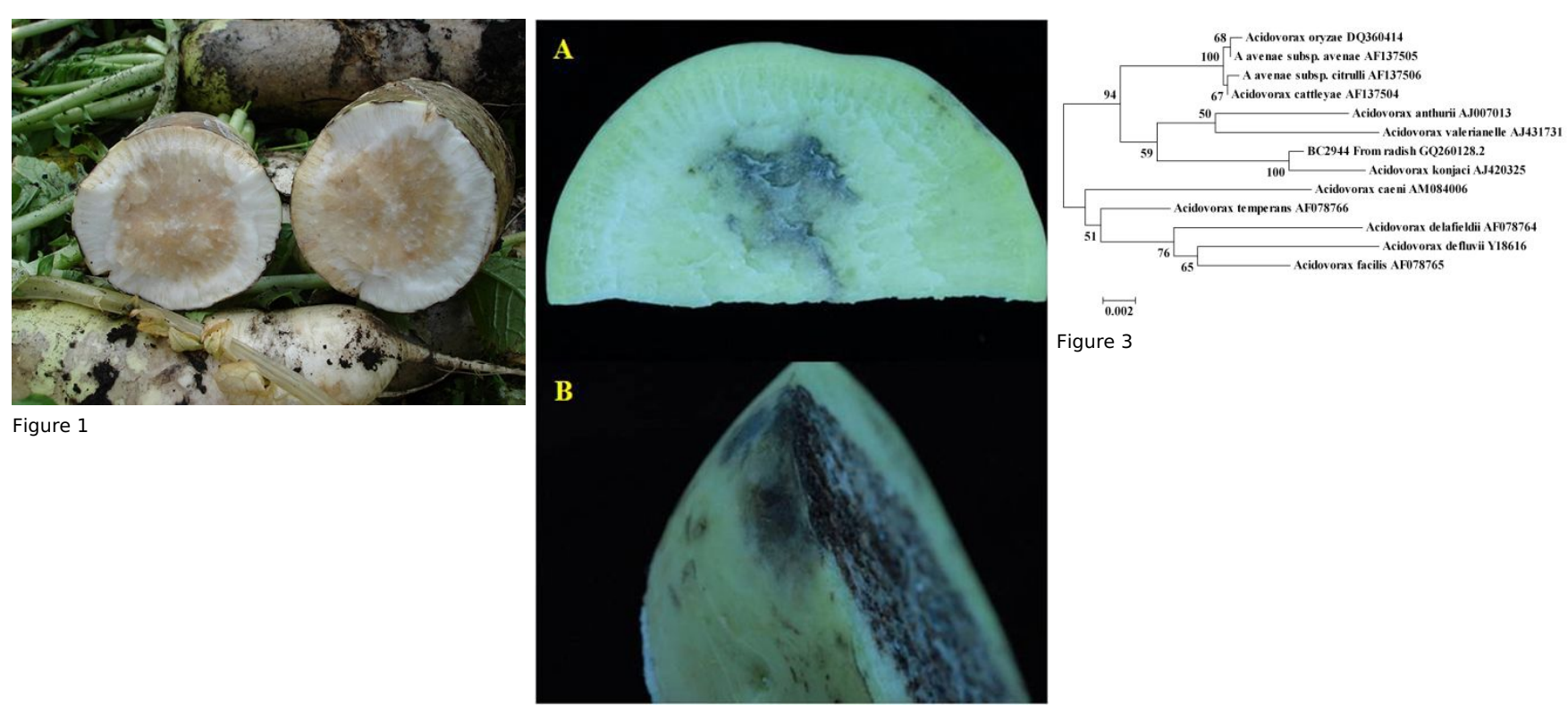

fragment (1442 bp) of the $16 \mathrm{~S}$ rDNA region of isolate BC 2944 was sequenced (GenBank Accession No. GQ260128.2) using universal primers and compared with the sequences of $16 \mathrm{~S}$ rDNA of the reference strains included in the genus Acidovorax available in GenBank. Isolate BC2944 clustered with $A$. konjaci in a phylogenetic tree obtained by the neighbour-joining method in MEGA Version 4.1 (Tamura et al., 2007) (Fig. 3). Based on the phenotypic, genetic, and pathological characteristics, all isolates were identified as A. konjaci. Bacterial leaf blight of konjac (Arnorphophalus konjac) caused by A. konjaci was previously reported in Japan by Goto (1983). To our knowledge, this is the first report of bacterial black rot caused by A. konjaci on Korean radish. We propose the name bacterial black rot for the disease.

\section{Acknowledgements}

The study was supported by the Agenda 7-28of the Rural Development Administration in Korea.

\section{References}

Goto M, 1983. Pseudomonas pseudoalcaligenes subsp. konjaci subsp. nov., the causal agent of bacterial leaf blight of konjac (Armorphophalus konjac Koch.). International Journal of Systematic Bacteriology 33, 539-545. [doi:10.1099/00207713-33-3-539]

Tamura K, Dudley J, Nei M, Kumar S, 2007. MEGA4: Molecular Evolutionary Genetics Analysis (MEGA) software version 4.0. Molecular Biology and Evolution 24, 1596-1599. [doi:10.1093/molbev/msm092]

Figure 2

To cite this report: Myung I-, Lee Y-, Jeong IH, Moon SY, Lee SW, Shim HS, 2010. A new disease, bacterial black rot of Korean radish, caused by Acidovorax konjaci. New Disease Reports 22, 26. [doi:10.5197/j.2044-0588.2010.022.026] 